\title{
THE POSTPHENOMENOLOGICAL CORPOREITY: ARTISTIC PRACTICES ON THE BORDERLINE BETWEEN ART AND SCIENCE
}

Keywords: postphenomenology, French phenomenology, art \& science, BioArt

\section{Introduction}

Phenomenology has developed tools to describe corporeality and has made it one of its main areas of intellectual investigation. The statement "Not only do I have my body, but I am my body" resonated most accurately in the phenomenological context. However, since Edmund Husserl, or even Maurice Merleau-Ponty, who pursued his master's project on an epic scale, phenomenology has sought new ways of discussing the body, both returning to well-explored areas and probing uncharted waters. It radicalizes

* Monika Murawska - Doctor Habilitated, philosopher and historian of art; Associate Professor and Acting Chair at the Theory Department, Faculty of Media Art at the Academy of Fine Arts in Warsaw. She is a French-Polish translator, author of numerous articles on French phenomenology, and the following books: Problem innego (2005), Filozofowanie z zamkniętymi oczami (2011) and Jean Renoir - malarz kadrów (2012); her fields of interests: aesthetics, French phenomenology, phenomenology.

Address for correspondence: Academy of Fine Arts, Krakowskie Przedmieście 5, 00-068 Warszawa, Poland. E-mail: monikamurawska@yahoo.fr. 
certain themes and becomes "heretical", as Paul Ricoeur puts it (Ricoeur, 1986). The impossibility of phenomenology as it was conceived by Husserl is emphasized, while its internal tensions, rifts and tears become revealed. Phenomenology revisits long-established and time-worn ideas, allowing them to approach and reflect reality anew. Thus, phenomenology becomes postphenomenology.

What is postphenomenology? ${ }^{1}$ To explain it briefly, I shall refer to an intriguing comparison made by Jérôme de Gramont in his book $A u$ commencement, where he likens phenomenology to wrestling with an angel, a Biblical image from the Old Testament (Gramont, 2013). It ought to be emphasized that several Biblical texts have provided a context for some of French postphenomenologists, e.g. Michel Henry, Jean-Luc Marion, Jean-Louis Chrétien or Jean-Luc Nancy. Gramont explains that interpreting

${ }^{1}$ Considering the notion of "postphenomenology", I do not follow Don Idhe and his books about postphenomenology (Ihde, 1993, 2010). In my endeavors, I draw from the work of David-François Sebbah and his L'épreuve de la limite. Derrida, Henry, Lévinas et la phénoménologie (Sebbah, 2001). I presented my conclusions in an article entitled Czym jest postfenomenologia? O (nie)możliwości fenomenologii [What is postphenomenology? On the (im)possibility of phenomenology] (Murawska, 2017). I focus on the analysis of the writings of French phenomenologists who draw inspiration from the philosophy of Husserl and Heidegger; they "escalate", as Sebbah puts it, that is, they highlight the importance of the source and search for something that transcends the visible and the perception. They associate source with excess, but also with the experience of astonishment, and ultimately the "trauma", i.e. crisis, the feeling of being torn, suffering or, like Lyotard, they negate the source while describing the power of visual excess. I strive to establish whether the thinkers I classify as postphenomenologists form a distinct group that includes - according to Sebbah - Emmanuel Levinas, Michel Henry, Jean-Luc Marion, Jacques Derrida and, beyond Sebbah's classification, philosophers whose main focus is aesthetics, i.e. Henri Maldiney, Alain Bonfand and Jean-François Lyotard. Maurice Merleau-Ponty stands, from this point of view, at the crossroads between phenomenology and postphenomenology. Consequently, "post-" in phenomenology does not imply any chronological order, but rather transgression, understood as phenomenology breaking its own borders, the radicalisation of certain formulas, emphasizing the importance of sensuality, a specific spectrality, that is, transformation of intentionality into a spectrum and, eventually, an attempt at excluding intentionality altogether from the experience of a work of art, or seeking new points of reference: in the case of phenomenologists analyzing art it would mean, for example, describing the work of new media artists or motion pictures, i.e. films, while reaching beyond the academic discourse and the struggle with language (I refer here, first and foremost, to the works of Levinas, Maldiney and Lyotard). 
phenomenology as wrestling with an angel means referring to the main elements of this story and showing that it can, in fact, be related to the dispute that takes place between logos and phenomenon: the phenomenon that appears and the word that tries to contain it. It is a battle of thoughts and we can surmise that even the thinker, in this case a phenomenologist, will not come out of it unscathed. In this battle, we put to the test our thinking, which recognizes that knowledge is born only out of our confrontation with things. The essence of phenomenology echoes Jacob's wrestling with an angel - a prolific confrontation in which the phenomenon and the logos constantly clash with one another. The confrontation itself is ill-fated and can only end in defeat, as it cannot adequately describe reality. It is destined to start over and over again.

If we accept this comparison or metaphor, we will also notice that postphenomenology is a phenomenology that has already wrestled with the angel and, although defeated, it has undergone a change, it has matured; Gramont argues that phenomenology, just as the Biblical Jacob, has been blessed. If phenomenology is dead, as some claim (Sparrow, 2014), it continues to exist as a ghost that haunts us, or as a spirit that remains present; it lives on as postphenomenology. This means that phenomenology, as postphenomenology, remains not only alive, but is perhaps more vigorous than ever, as a phantom.

Postphenomenological approach to the problem of corporeality seems somewhat different, which is most pointedly evidenced by Henri Maldiney's reflections, or the work of Jean-François Lyotard, on the borderline of phenomenology. They perceive subjectivity as sensual and affective, haunted by the sensual fact and, paradoxically, formed in an act tantamount to its destruction and abolition. For it is the body that plays the main role in this sensual and hypertrophic haunting by the sensual.

On the other hand, the body also turns out to be invisible and filled with symbolism, it refers to the metaphysical dimension, turning us towards incarnation in the Christian sense, which is superbly illustrated in the writings of Michel Henry and Jean-Luc Marion, but also Jean-Louis Chrétien. From this perspective, we can concur with Chrétien's claim that the various dimensions of corporeality are intertwined, and that the physical body serves as support for symbolism associated with it, and it intertwines with the collective body, which refers to the image of Christ. 
Taking into account both directions of the postphenomenological thought, let us quote the radical opinion of Renaud Barbaras, who claims that today the philosophy of the body must be the phenomenology of the body. "The philosophy of the body can only be fulfilled as the phenomenology of the body", argues Barbaras, because only phenomenology is capable of grasping the fleeting phenomenon of corporeality (Barbaras, 2005, p. 210); it is in the possession of exclusive tools that can bring us closer to understanding this shifting and multilevel phenomenon. The question that arises in this context, and one that I shall try to answer, is: Can the philosophy of the body be fulfilled, and is it fulfilled as the postphenomenology of the body?

It is at the intersection of these two radical concepts of corporeity in postphenomenology that I wish to reflect on the body in artistic practices that go beyond performance and become transgressive, making use of new technologies, experimental biology and cytogenetics.

The postphenomenological body is both sensual and spiritual. It is pure experience, sensation and transcendence. It is ambivalent, perhaps even paradoxical. As such, it seems a perfectly suitable tool for describing the work of artists who, for instance, have an ear transplanted onto his forearm (Stelarc), create a genetic hybrid through the mixing human genes with the genes of petunia (Eduardo Kac), or make bread containing fragments of their own DNA with a view to ritually consuming it (Karolina Żyniewicz). Is radical postphenomenology able to grapple with the radicalism of artistic and art \& science practices in a cognitively prolific gesture?

It ought to be mentioned that phenomenology addresses matters of technology and its development as neurophenomenology, connected with cognitive science; however, Husserl and Merleau-Ponty (Przegalińska, 2016) tend to be the only phenomenologists to whom reference is made in such interpretations. The perspective I intend to adopt here is quite different.

Let us begin with a brief presentation of postphenomenological concepts of corporeity. I shall not discuss postphenomenology and the philosophy of specific thinkers in detail, but rather provide a concise and instrumental description of a number of basic categories associated with them that may prove useful for the interpretation of selected artistic acts. 


\section{Corporeity as field of sensibility - Henri Maldiney and Jean François Lyotard}

Henri Maldiney, whose conceptual tools are derived from psychopathology, follows in the footsteps of Merleau-Ponty, while persistently criticizing him. In his view, the body is being there (être-le-là) ${ }^{2}$, but its verticality allows it to be both "here" - in one specific place - and "there", when it moves elsewhere through sight (Maldiney, 2003). These ideas have been recurrent in phenomenology since its very inception: from Husserl, to Heidegger, to Nancy. Seen from this perspective, the body can, with the help of senses, expand the field of its experience, hear sounds from behind a wall, see what happens two meters away from it, touch something that is within an arm's reach. This peculiar "being in everything" that surrounds it is related to the ecstatic nature of our body, to its constant attempts at reaching beyond itself. What remains far away, comes closer, and what is close can be far away, as illustrated by examples provided by Heidegger - undeniably an important point of reference for Maldiney - who refers in this context to glasses or binoculars (Heidegger, 1996).

According to Merleau-Ponty, my visible body immerses me in the visible, as the one who sees does not appropriate what (s)he sees, but approaches it with his/her gaze (Merleau-Ponty, 1985). Maldiney, just as Merleau-Ponty, emphasizes the importance of seeing, although his approach is slightly different. He writes: I see where I am and I am where I see (Maldiney, 2013). I see where I am, because what I see and what I experience depends on where I am. At the same time, I am where I see, because what I see allows me to be situated in space and, consequently, my field of vision becomes the basis of what I experience. At the same time, however, "here" and "there" mingle with each other, because, I exist in the Opening, as Maldiney writes, and therefore I am in every place to which my body can take me through my senses.

The experience in question is absolutely unintentional, so we cannot refer it to any particular object or any specific phenomenon. There is no noesis or noema, there is no intentionality or, in other words, we are not directed towards anything. The experience referred to by Maldiney seems to resemble affects - pain or pleasure - that spread through the body, eluding any

${ }^{2}$ The expression “être-le-là" is one of French translations of Heidegger's Dasein. 
attempts at concretization, or intentionality, which Husserl himself explored in Logical Investigations (Husserl, 2001). The pain is that of a particular part of the body; it spreads throughout the body, or, to use Husserl's example, resembles itching that is impossible to spot.

According to Maldiney, the body is always connected with the world, it represents the pre-conceptual, intuitive and sensory dimension of feeling; it is a specific spatio-temporal expression of feeling which in Maldiney's essay entitled L'art et le pouvoir du fond [Art and the Power of Depth] in Regard parole espace, is described as a "tension between closeness and distance" (Maldiney 2015, p. 231). This contact with the world and experience contain the diastolic exaltation (Greek diastole - extension) and systolic concentration (Greek systole - contraction), and thus involve the abandonment and the acceptance of the world, proximity to and detachment from it. They derive from the opaqueness of the world, its resistance and the inevitable confrontation with our inability to fully grasp it. They are also due to its inescapable closeness. Communication with the world, which has yet to be "crystallized" into ready-made objects, does not allow us to experience a specific thing, or "what" appears, but we can experience "that" and "how" it appears; this forms the basis of everything that is. It would be a non-thematized source experience, phenomenality prior to any reference to a perceived object, a moment connected with the dual movement of expansion and contraction. As such, it is a painful and confusing experience that makes one feel that all foundations suddenly crumble. Maldiney associates this experience primarily with works of art.

However, one can ask how this dual movement, of accepting the world and distancing oneself from it, that is, the diastolic and the systolic movement consonant with the rhythm of our breath, occurs. For it is in the act of breathing that we inhale and release air, there is systole and diastole, and our body is subject to a specific rhythm that subordinates everything to itself; we give in to the "breathing: you invisible poem!"3, as Reiner Maria Rilke put it (Rilke, 1987, II) .

When commenting on Merleau-Ponty's essay, Maldiney refers to Rilke's sonnet mentioned above (Maldiney, 1988). It is an apt illustration of the coexistence of the body and the world presented by Maldiney. However,

${ }^{3}$ Breathing: you invisible poem! Complete / interchange of your own / essence with world-space. You counterweight / in which I rhythmically happen. 
in the experience that Maldiney describes, the idea is to run out of breath and to stop the breath in order to disrupt the rhythmic process of inhaling and exhaling. This coexistence is not harmonious, but, as Iwona Lorenc puts it, dissensual (Lorenc, 2014). The experience described by Maldiney, which forms the basis of our co-existence with the world, and whose paradigm is the experience of a work of art, turns out to distort, change and generate a crisis.

This line of argument seems to be pursued also by Jean-Francois Lyotard, whose late writings, in particular those devoted to art, can be considered postphenomenological (Lyotard, 2012). Lyotard's first book Discours, figure (1971) thematizes artistic work as a deconstruction of assumptions that subordinate a work of art to the requirements of communication. A work of art does not uncover the truth, but disrupts it in an act of "derealisation", which is also a psychological disorder that involves a distorted perception of the surrounding world. A person suffering from derealization is under the impression that the world around him/her has somehow changed. Therefore, the artist does not create his/her art in order to respond to questions about rights implied by perception and does not explain rules that govern it, but rather reveals that no such rules exist, that one should not trust the eye whose movements rationalize and refer to its own activity. The aim is rather becoming lost in vision or lost in visuality, which Lyotard distinguishes from visibility - a notion crucial for earlier phenomenologists. Visuality is in his philosophy pure sensuality. Unlike Merleau-Ponty's act of seeing, it does not reveal reality as it is being born, but proves that reality always eludes us, and therefore remains out of our reach (Bernard, 2014). We can only seemingly capture what is given, and it is only seemingly stable and durable. Rather, the endeavor consists in making visible the remnants of what constantly evades us. We try to capture what the reality given in the gaze obscures. The purpose of art is not to show reality, but to expose the illusion of cognitive completeness. The artist can achieve it only when (s)he is able to exploit and make use the impotence (s)he experiences. This is why "derepresentation", the unrealness present in works of art, can be described as revealing the source of the impotence of the very act of perception, its powerlessness against the sensual chaos, but also impotence understood as inability to reproduce an object, even in accordance with classic rules of perspective, which deceive us, as they only tell us what reality should look like if we subordinated it to the rules of geometry. This impotence is the very essence of the secret of "active passivity" - French passibilité and not 
passivité - important for both Lyotard and Maldiney. Maldiney also refers to it transpassibility (transpassibilité) which is hyperpassiveness (Maldiney, 2007).

Thus, Lyotard concludes that the artist is able to reveal elementary experiences hidden in the ordinary, everyday perception, but it requires a certain asceticism, which deprives the perceptual and mental field of the superstition inscribed in vision itself. This type of feeling (le sentir) was also the object of Maldiney's quest. The latter even went as far as stating that we are not able to control or master it. After all, these experiences, visual or auditory, have yet to be formed by perception. Therefore, he opposed feeling and sensation as pathos to rationalizing perception. To him, the truth of feeling understood in this manner is art - a specific work we are confronted with.

According to Lyotard, experience as sensation stops the intrigue and destroys all synthetic activity. This act of expropriation goes so far that the gesture is no longer the gesture of the artist, or the subject, but of the Thing, as referred to by Lyotard (Lyotard, 2009). Thus, art turns to what is not human, and so to what is in-human, that is, independent of a human being; these are forces beyond human control. Thus, art links what is human with what is inhuman (Lyotard, 1991).

Art shifts us to the sphere of audibility and visibility of what is inaudible and invisible, and what belongs to the sphere of fundamental passivity, the aforementioned state of hyperpassivenness associated with our sensuality, saturated with the fear of death or associated with the threat of death. In short, it is about excess in sensuality, the excess that resists (being fully grasped, understood, appropriated). However, it can be argued that the conclusion regarding art formulated by Lyotard in Moralités postmodernes (entitled in English translation as Postmoderne Fable) is a meditation on the essence of sensuality in its connection with death (Lyotard, 1999). It is most aptly expressed when Lyotard claims that if a work is art, it testifies to excess in relation to what the body can feel, it evidences the excess of sensuality understood as all bodily institutions (biological and cultural). One might audaciously speculate that this excess is basically an experience, or even the matter of experience, but perhaps it is nowhere to be found. Experience cannot be reduced to the acceptance of contextualized and useful information. It evokes, simultaneously and immediately, a threat. The body does not exist for itself, but it is sensual only in so far as it is exposed to another thing, deprived of its own reticence when confronted with the risk 
of annihilation. It is sensual only when it becomes pathetic and pitiful (Lyotard, 1999).

The abyss of death drills into the body and deepens the experience. In our opening to the world, we are, ultimately, destined to it by fate. Art bring us closer to this abyss, yet without allowing us to sink into it.

The problem is expounded differently in another chapter of Moralités postmodernes. Once again, Lyotard describes our sensual condition and claims that our soul, the minimal and momentary anima minima, depends on it. Subjectivity is, according to Lyotard, a temporary state, dependent on stimulation, and it emerges only to immediately disappear. It remains in a state of continuous becoming and disintegration. He says that experience creates a breach in our inert existence. It alerts existence, or rather makes it exist. What we call life derives from externally inflicted violence that interrupts lethargy. Anima only exists when forced to do so. Aistheton pulls the inanimate out of the abyss of non-existence, pierces the vacuum with its lightning, and allows the soul to emerge from it. The sound, the smell and the color bring out the pulse of feeling straight from this neutral continuum, from emptiness (Lyotard, 1999). It is art that allows anima minima, which also means the stimulation of the body, to exist.

\section{Corporeity as Spiritual Reality - Michel Henry, Jean-Luc Marion and Jean Louis Chrétien}

In the second postphenomenological approach, the body is the living corporeality, this is the flesh, or in French la chair. According to Michel Henry, a living flesh is the self that is a perfect exemplification of one's unmediated relationship with oneself (Henry, 2015b). Immanence - the embodied selfis also radical passivity, being without any distance from oneself, the very being that becomes its own substance. Michel Henry describes the flesh as self-stimulating (auto-affecté) and, unlike the concepts presented above, as enclosed, because la chair is experienced internally, while le corps - the body - is exposed to the light of the world. Henry claims that one's body is not, however, like a mountain that one can see from one side or the other, nor is it an object that one always perceives from a single point of view, or a thing can be explored from the outside. I can never see my body from the outside, because I am never outside of my own body (Henry, 2015c). In this 
way, our corporeity functions as a unity - the basis of the transcendental dimension and, at the same time, as one of its elements. For the corporeity has an inside and an outside. Ultimately, Henry claims that we experience its outside, but we feel the inside which, eventually, conditions all other dimensions. The body must oscillate, appearing to us as objective and subjective. Depending on how we look at it, it may be the living flesh - la chair, or a transcendent body - le corps. According to Henry, the boundary between the invisible world of our corporeality, to which our objective body belongs, and therefore the very body perceived from the outside - this line between the visible and the invisible, where both our kinaesthetic impressions and sensations originating from our senses come into existence is the skin as Henry underlines in Incarnation (Henry, 2015a). The skin would cover or hide the invisible reality of human corporeality, inaccessible to the eyes even on an X-ray film. What it reveals to a physician are only individual organs - the mystery of their functioning, the unity, the harmony all remain inscrutable. After all, often a doctor does not know when and why a disease appears, or when and why it suddenly subsides.

My living flesh, which is neither a thing nor a tool, is in Henry's concept my Self in the world and an absolute dimension conditioning all other dimensions of corporeality. Ultimately, therefore, I never use my flesh solely as a tool, because even where I use it, I am still sustained by it in order to act and carry out various operations, to receive stimuli and encounter things. We may even venture a claim that, according to Henry, I am not my body (corps), I am my living flesh (chair). The objective, and at the same time representational dimension of my body is not important: it is not me. I may never look at myself in the mirror, I may make contact with others in the virtual world, where no one will see my body, yet my Self will always be my living flesh, my pain, my manual skills, my abilities. Let us reiterate: I am my "living flesh". It is my Self in the world. At the same time, however, it has metaphysical traits, for it allows me to discover the original Son, the Arch-Son in me (Henry, 2015a). Ultimately, my embodiment refers to incarnation in the Christian sense.

Henry's concept had an unquestionable impact on Marion's phenomenology. The living flesh - la chair - is one of the phenomena that he describes as saturated (saturés), next to the event, the icon and the idol. According to Marion, phenomena known from the history of philosophy 
are afflicted by the lack of intuition. This deficiency limits their givenness themselves in an intuitive act.

That is why Marion describes in his phenomenology a different kind of phenomena, which he calls saturated (Marion, 2002). These are the phenomena whose givenness, and thus intuition, exceeds the possibilities of an intentional act in which such a phenomenon could be constituted. A saturated phenomenon is, therefore, irreducible to the conditions of the experience of cognizing consciousness. These phenomena appear within themselves, and Marion calls them paradoxes.

The category of the corporeity is also important for Marion in the context of his meditations on the gift. When someone uses another person as an object, (s)he excludes that person from the act of givenness. The most radical act of self-givenness is, undoubtedly, the givenness of one's own body, but it seems that this kind of givenness can easily be transformed into a mere "use". The gift of oneself to another person may involve certain objective manifestations, for instance a wedding ring. This, however, only emphasizes the inadequacy of such objects and the fact that they cannot be identified with the gift itself (Marion, 2002). The body, however, can become a gift, when we consider its invisible, non-object side, or the body as la chair. Marion recognizes that an athlete, an artist or a lover, each in their own way, give pleasure to different recipients: the attainment of the desired result and a victory, an aesthetic experience, or erotic pleasure. However, none of them knows anything about the pleasure (s)he gives; they may know whether, when and to what extent they provide it - which is already a lot and usually requires the recipient to state or confirm it, or even lie about it (Marion, 2002). What the three individuals mentioned above have in common is the act of giving themselves to the Other, which would be a positive description of the givenness of phenomenon as the gift considered by the donor, as clearly emphasized by Wojciech Starzyński (Starzyński, 2009). The artist does not know exactly the gift (s)he makes to others. From this point of view, the artist does not expect gratitude, and the givenness remains a mystery to him/her.

Art turns out to be very important in this context, as it unveils the affectiveness of the experience as such (according to Henry), and the weight, as Marion puts it, of the gift itself, in other words the givenness of the phenomenon itself. 
Jean-Louis Chrétien also explores the body in the Christian context. He investigates corporeality, inter alia, in the book entitled Symbolique du corps (Chrétien, 2005). According to Chrétien, the song of love, or the Biblical Song of Songs, is also a song of the body, the body of a woman and of a man who exalt individual elements of their corporeality. Each chapter of Chrétien's book describes a particular element of the body: teeth, nose, lips, eyes, cheeks, hair, breasts, stomach, navel, hands, legs and feet (explored in this order in subsequent chapters). The book analyzes the meaning and constitution of the symbolism of corporeality, from the outset of Christianity, that is from Origen, Augustine, St. Bernard, to their successors: Luther, Francis de Sales or poet Paul Claudel. What can our members do? What is their symbolism? How far does the clarity of the body extend, and where does our ability to express it end? What belongs to the community, identified with the body? These are the questions that Chretien strives to answer in his work (Chrétien, 2005).

The importance of the body is mediated through a variety of actions and gestures performed by individual parts of our body. The symbolism of the described members is twofold: it refers to the collective body of the community, and to the power hidden in what Chrétien calls "the inner human", as opposed to the classically defined substantive subjectivity. The philosopher reveals fundamental dimensions of Christian thought about the body, which has marked our language and our attitude towards the world in different ways, and where it remains until today.

\section{Postphenomenological Corporeity and Art and Science}

How can the notions outlined here, which I refer to as postphenomenological, be used to describe radical art \& science practices? Does "the aesthetic turn in phenomenology", as pointed out by Maryvonne Saison (Saison, 1999) also encompass a description of artistic activities that rely on corporality, but transgress it, perhaps pushing further its boundaries? Can actions of artists representing art \& science be comprised in the phenomenological and/or postphenomenological description, assuming, on the one hand, the supremacy of sensibility and, on the other hand, the specific sacrality of corporeality, and its ties with transcendence? Putting it differently, the question is whether artistic actions I have selected break open the conceptual 
framework of postphenomenology, or whether they expand the limits of discourse concerning art practices.

In an attempt to answer these questions, I shall reiterate that the radicalism of postphenomenological concepts can be compared to the radicalism of art \& science (Scott, 2011). This artistic phenomenon itself seems heterogeneous and difficult to grasp; it eludes any precise definition. Karolina Żyniewicz recounts it very interestingly when she writes about art \& science as a liminal and borderline phenomenon. Even its spelling varies: "art and science" emphasizes the separation of the two areas, while "art\&science" does the exact opposite (Żyniewicz, 2018).

In my analysis, I shall focus on BioArt (Daubner, Poissante, 2013). Let us begin by recalling Stelarc's famous act which involved the transplantation of the artist's ear onto his forearm, or the much publicised action of Eduardo Kac, who used his own DNA and the DNA of petunia to create a new plant, which he named Edunia. However, in the context of postphenomenological concepts presented above, I wish to discuss projects that are more recent, yet not less controversial.

The documentation of Karolina Żyniewicz's 2018 project entitled The Last Supper contains the following description: "Yeast modified with my genes were used to produce beer and bread, which were the main foods served during the supper. Association with a certain well-known miracle are obvious. It refers to one of the most famous motifs in the history of art, the painting The Last Supper by Leonardo da Vinci, and to the Christian tradition". We may wonder whether foods produced using organisms that had the artist's gene have the Christian symbolism that mentioned postphenomenologists wrote about? Is food transformed in this manner unacceptable?

The second example that I wish describe is Marion Laval-Jeantet's work of 2011. The artist injected herself horse blood plasma. It was entitled May the Horse Live in Me! Horse blood (plasma) was introduced into a human body by means of an injection. The blood of an animal was expected to become compatible with the human body and to have a positive effect on it. Marion Laval-Jeantet experimented with different horse immunoglobulins. She stated that her intention was to trigger with this "blood ritual" a discussion about barriers between species and the superiority of humans over animals.

Acts described above involved broadly understood interference in one's own body, its extensiveness, as well as its transformation. It seems that Stelarc's and Laval-Jeantet's actions, thanks to commentaries, may be 
considered a continuation of the discursive axis that emphasizes the meaning of the sensibility, and the fact that our body testifies to our fragility, is an element of expropriation, the absence of identity, otherness with which we are confronted, and which becomes an immanent component of corporality. This brings to mind the work of the German phenomenologist Bernard Waldenfels who writes about "the alien" as an important component of our experience of subjectivity (Waldenfels, 2011). In Polish philosophical literature, the body in this context has been superbly analyzed by Monika Rogowska-Stangret, who explores body as alien, as otherness, writing about body-fragments, or body-assemblage, thus reaching beyond standard dualisms in which the body is entangled (Rogowska-Stangret, 2016).

At first, Laval-Jeantet feels that her own body is alien, other, unfamiliar, foreign. She watches herself closely, experiencing herself and reality, which she confronts more intensely and differently. According to Lyotard, the experience is understood as a violent intrusion of something that awakens us, produces a cell of feeling that he calls minima anima. It rises within us, letting subjectivity shine for a moment. In the context of sensuous conditions of existence, it is natural to fear that nothing will ever come again to wake us up: the fear that we will not feel anything anymore, that we will not be awakened by the emerging minima anima. The sensuous contains in itself the threat of death, but in two different manners: either as a threat that the sensual will become excess and either dissolve or brutally swallow us, or a threat that the sensual will never return (death means that one will not feel anything anymore).

Injecting horse's blood plasma would obviously be a threat in the literal sense: human body's reaction to it was unpredictable. The act also involves a literal connection of what is human and inhuman. In this case, inhuman means not only what is animal, but - from the perspective of Lyotard, for whom it is an extremely important category (Lyotard, 1991) - also succumbing to forces one cannot control. Inhuman (l'inhumain) represents what cannot be encoded and transformed into transferable digital data, claims Lyotard. It destabilizes any social regulations that have been imposed top-down. We are not automated cogs in the development machine. When referring to the inhuman, Lyotard has in mind forces that an individual cannot control, and which governed the body of Laval-Jeantet. Maldiney conceived subjectivity in a similar manner: as deeply affective, always foreign to itself, as being born through an experience so strong that may result in 
destruction. An aesthetic experience means a break with what is ordinary, usual, familiar and safe. It testifies rather to the dissolution of reality than to its cohesion and familiarity. From this perspective, Laval-Jeantet's action appears to be paradigmatic.

When discussing the expansion of the field of one's own bodily sphere and intensifying the experience, we should mention Neil Harbisson and Moon Ribas. Neil Harbisson suffers from a rare form of color-blindness called archromatopsia, which means that he sees the world in greys. It is caused by an insufficient number of brain cells responsible for seeing colors. In 2004, together with Adam Montandon, an IT specialist, he created a device processing colors - light waves - and transforming them into sounds. He called it an eyeborg - the eye of a cyborg. An antenna placed above his head allows him to capture colors inaccessible to his brain. It is a physical extension of the body with an additional "sense" that transmits vibrations through an implant into his skull. This affects Harbisson's perception of the surrounding reality. An accumulation of colors translates into a profusion of sounds. As Harbisson is also a musician, he is capable of using the sounds he hears to compose music. The antenna placed on his head has changed his way of looking at people: he does not perceive them as attractive or ugly, but as pleasantly or unpleasantly sounding. This additional sensor located above the head forms an integral part of his body and cannot be removed.

In an attempt to refine her sensory experience Moon Ribas, Neil Harbisson's partner, has had a seismograph surgically implanted in her body, which allows her to feel the vibrations of earthquakes. The chip implanted in the body transmits vibrations from throughout the world, with varying intensity depending on the strength of the earthquake. In her performances Waiting for Earthquakes, the artist stands and waits for vibrations that she will be able to feel. She then performs a dance, choreographed by the intensity of the earthquake. It is an example of extensiveness of the field of one's experience which becomes expanded by further dimensions. This intensification of experiences may be equated with the stimulus, very important for Lyotard and explored also by Maldiney, associated with hyperpassiveness that intensifies experience and makes it more vivid. The above artistic acts are examples of artists' attempts at extending their own bodily sphere.

Żyniewicz performs this extension slightly differently. Is there space in the phenomenological or postphenomenological description for combining the human gene with another, and thus for transferring oneself outside? For 
a literal transcendence of oneself? Given the title of the work itself - The Last Supper - wouldn't Henry's, Marion's and Chrétien's descriptions, in which they refer to certain notions of Christian theology, be most fitting for analyzing Żyniewicz's work, in particular given its title? Could they not guide us in our attempts to describe Karolina Żyniewicz's art?

A certain theological theme is tantamount to all of Michel Henry's philosophy, although it is not dogmatic and remains controversial. The philosopher endeavors to show that one's relationship with another person can be defined and interpreted exclusively through the prism of Christianity, in which the body is associated with the mystical body of Christ. Living flesh (la chair) is also the place of Salvation and it is from this perspective that it turns out to be inhabited by absolute Life. Corporeality is essentially ambiguous. From the Christian viewpoint, explored by Henry in the third part of Incarnation, the body is always associated with redemption, and at the same time with sin and fall.

In Incarnation Michel Henry endeavors to show how "in the depth of the Night", in the experience of living corporeality, our living flesh transpires to be the Original Revelation, Arch-revelation of Life, and God (Henry, 2015a). Our living flesh is God, because Christ is the incarnate Word that revealed itself to humans. Consequently, it can be concluded that our corporeity - la chair - allows us to participate in the incarnation of God, allows us to understand the words of St John: "And the Word became flesh". Therefore, as part of Henry's reflections on the problem of intersubjectivity, the idea of original Self and Life, inscribed in every individual and particular self, finally appears (Henry, 2015a). Through experiencing my own life, I experience both myself and the intersubjective sphere.

Living corporeity is a life that I share with others, transposed into bread and beer by Żyniewicz. She allowed us to see the invisible, that is, let living corporality, available only in the intimate experience of my interior, to reveal itself. Henry claims that it is only through living corporeity that I can experience the other. From this perspective, Żyniewicz accomplished the impossible: an act of literal sharing of her own body. By doing so, she established a specific "community", a group united by the gesture of sharing the body, which established an ephemeral "symbolic body" referred to by Chrétien, sanctified by a quasi-ritual act.

She also makes a gift of her body. Is it an objectifying gesture, or is her act simply characterized by the unselfishness typical of a gift, as described 
by Marion? It seems that it is the waiting acceptance of the gift as such that allows us to accept unacceptable excess - an essential condition of its existence according to Marion. As Urszula Idziak puts it in relation to Marion's philosophy, the gift transpires to be possible only as an act or as sacrifice, it is the madness of decision (Idziak, 2009, p. 26). In addition, Marion refers to the subject he describes as adonné - "gifted", devoted or given over to (Marion, 2002). Żyniewicz gives away part of her gene, gives herself in the "madness of decision", which can be interpreted as sacrifice. Her gift thus becomes a saturated phenomenon.

In this context, one may also quote Nancy's cogent argument from his well-known book Corpus, whose first version was a paper delivered at a scientific conference Bodies, Technologies: "The anxiety, the desire to see, touch, and eat the body of God, to he that body and be nothing but that, forms the principle on Western (un)reason. That's why the body, bodily, never happens least of all when its named and eonz/o/eed" (Nancy, 2008, p. 5). This is precisely what body is in Karolina Żyniewicz's work: uprooted, torn out of a place, scattered in bread and beer, and sanctified. This is presentation of our desire to see, touch and eat the body (of God who became human) present in Christianity, body that is ambiguous and multidimensional, sinful and saint at the same time.

Needless to say, this interpretation goes far beyond the intentions of philosophers themselves, reversing their assumptions deeply embedded in Christian theology. Nevertheless, conceptual tools developed by them have been kept. Echoing Ricoerian descriptions of theories developed by Husserl's successors, we can qualify this interpretation as "heretical".

\section{Conclusions}

Phenomenologists discussed above have explored art and they have undoubtedly influenced what Maryvonne Saison refers to as the "aesthetic turn in phenomenology". They have not commented on the artistic acts described above; nevertheless, conceptual tools they developed seem so compelling that I decided to use them to present selected works of art \& science, which Marc Jimanez calls "augmented aesthetics" (esthétique augmentée) (Jimanez, 2010 , p. 97). This strategy allows us to show that postphenomenology, which eludes the socio-political context and constantly endeavors to get 
to "things themselves" is suitable for the interpretation of the most recent artistic phenomena. Suffice it to recall the telling title of one of Lyotard's better known essays: Philosophy and Painting in the Age of their Experimentation (Lyotard, 1984). Artworks referred to above are clearly examples of artistic experimentation.

Acts described above are certainly not the last word, or rather the last gesture of artists who use their body, its DNA, structure and ambiguity in their artistic practices. There is no end to the body's song, as Chrétien concluded in his book (Chrétien, 2005).

And as long as there is a phenomenon, the phenomenologist will wrestle with it, although, as Monika Rogowska-Stangret puts it, "extremely different stories of searching for the truth in the body leave us helpless in the light of the - real or supposed? - mystery of the body" (Rogowska-Stangret, 2016, p. 10). The postphenomenological corporeity, sensible and sacred at the same time, confronted with the actions of art \& science artists, reveals itself in all its helplessness. This is precisely why it is so fascinating.

Translated by Matgorzata Dera

\section{References}

Barbaras, R. (2005). De la phénoménologie du corps à l'ontologie de la chair. In: J.-Ch. Goddard (ed.), Le corps (pp. 2017-250). Paris: Vrin.

Bernard, G. (2014). Art et épokhè. Le doute de Lyotard. In: F. Coblence, M. Enaudeau (eds.), Lyotard et les arts (pp. 119-132). Paris: Klincksieck.

Chrétien, J.-L. (2005). Symbolique du corps. La tradition chrétienne du Cantique des Cantiques. Paris: Presses Universitaires de France.

Daubner, E., Poissante, L. (2013). BioArt: transformations du vivant. Québec: Presses de l'Université du Québec.

Gramont, de J. (2013). Au commencement. Parole, Regard, Affect. Paris: Cerf.

Heidegger, M. (1996). Being and Time. Trans. J. Stambaugh. New York: State University of New York Press.

Henry, M. (2015a). Incarnation: A Philosophy of Flesh. Trans. K. Hefty. Evaston, IL: Northwestern University Press

Henry, M. (2015b). Phénoménologie de la vie. Paris: Presses Universitaires de France. 
Henry, M. (2015c). Philosophie et phénoménologie du corps. Paris: Presses Universitaires de France.

Husserl, E. (2001). Logical Investigations. Vol. I. Trans. J.N. Findlay. Routledge.

Idziak, U. (2009). Dar. Spór między Jeanem-Lukiem Marionem a Jacques'em Derridą. Kraków: Wydawnictwo A.

Ihde, D. (1993). Postphenomenology: Essays in the Postmodern Context. Evaston, IL: Northwestern University Press.

Ihde, D. (2010). Heidegger's Technologies: Postphenomenological Perspectives. New York: Fordham University Press.

Jimanez, M. (2010). Art et technoscience. BioArt et neuroesthétique. Paris: Klincksieck.

Lorenc, I. (2014). Estetyczne problemy późnej nowoczesności. Toruń: Wydawnictwo UMK.

Lyotard, J.-F. (1984). Philosophy and Painting in the Age of Their Experimentation: Contribution to an Idea of Postmodernity. Trans. M.M. Brewer, D. Brewer. Camera Obscura, 4 (3 [12]), 110-125.

Lyotard, J.-F. (1991). The Inhuman. Reflections on Time. Trans. G. Bennington, R. Bowlby. Stanford, CA: Stanford University Press.

Lyotard, J.-F. (1999). Postmoderne Fables. Trans. G. Van den Abbeele. Minneapolis: University of Minnesota Press.

Lyotard, J.-F. (2009). Karel Appel. Le geste de couleur. French-English Version. Leuven: Leuven University Press.

Lyotard, J.-F. (2012). Que peindre? Adami, Arakawa, Buren. French-English Version. Leuven: Leuven University Press.

Maldiney, H. (1988). Chair et verbe dans la philosophie de M. Merleau-Ponty. In: A.-T. Tymieniecka (ed.), Maurice Merleau-Ponty, le psychique et le corporel (pp. 55-88). Paris: Aubier.

Maldiney, H. (2003). Art et existence. Paris: Klincksieck.

Maldiney, H. (2007). Penser l'homme et la folie. Grenoble: Millon.

Maldiney, H. (2013). Regard Parole Espace. Paris: Cerf.

Marion, J.-L. (2002). Being Given: Toward a Phenomenology of Givenness. Trans. J.L. Kosky. Stanford, CA: Stanford University Press.

Merleau-Ponty, M. (1985). L'Eil et l'Esprit. Paris: Gallimard. 
Murawska, M. (2017). Czym jest postfenomenologia francuska? Rozważania o (nie) możliwości fenomenologii. In: M. Poręba, B. Działoszyński (eds.), Między metafizyka a fenomenologia. W stronę Jacka Migasińskiego (pp. 85-105). Warszawa: Wydawnictwa Uniwersytetu Warszawskiego.

Nancy, J.-L. (2008). Corpus. Trans. R.A. Rand. New York: Fordham University Press.

Przegalińska, A. (2016). Jak fenomenologia zmieniła sztuczna inteligencję. Istoty wirtualne. Kraków: Universitas.

Ricoeur, P. (1985). A l'école de la phénoménologie. Paris: Vrin.

Rilke, R.M. (1987). Sonnets to Orpheus. Trans. D. Young. German-English Edition. Middletown: Wesleyan University Press.

Rogowska-Stangret, M. (2016). Ciało - poza Innościa i Tożsamością. Gdańsk: Fundacja Terytoria Książki.

Saison, M. (1999). Le tournant esthétique de la phénoménologie. Revue d'esthétique, $36,125-140$.

Scott, J. (2011). Artists-in-Labs. Networking in the Margins. Wien-New York: Springer.

Sebbah, D.-F. (2001). L'épreuve de la limite. Derrida, Henry, Lévinas et la phénoménologie. Paris: Presses Universitaires de France.

Sparrow, T. (2014). The End of Phenomenology: Metaphysics and the New Realism. Edinburgh: Edinburgh University Press.

Starzyński, W. (2009). Drogi fenomenologii donacji Jean-Luc Mariona: redukcja, intencja, obraz, dar. Białystok: Wydawnictwo Uniwersytetu w Białymstoku.

Waldenfels, B. (2011). Phenomenology of the Alien: Basic Concepts. Trans. T. Stähler, A. Kozin. Evaston, IL: Northwestern University Press.

Żyniewicz, K. (2018). Nie sztuka i nie nauka. Art\&science jako strategia liminalna (strategia bycia „pomiędzy”). In: A. Panek, M. Murawska, W. Krassowski (eds.), Wpływ wspótczesnej nauki na rozwój sztuk wizualnych (pp. 6-15). Warszawa: Wydawnictwo ASP. 


\title{
Online sources - art projects
}

Eduardo Kac. Natural History of the Enigma. Retrieved from: https://www.ekac. org/nat.hist.enig.html (29.05.2019).

Karolina Żyniewicz. The Last Supper. Retrieved from: http://karolinazyniewicz. com/gallery/the-last-supper/ (29.05.2019).

Marion Laval-Jeantet. May the Horse Live in Me. Retrieved from: https://www. youtube.com/watch? $\mathrm{v}=\mathrm{Awz} 4 \mathrm{w} 22 \mathrm{tFHw}(29.05 .2019)$.

Neil Harbisson, Moon Ribas. Retrieved from: https://www.cyborgarts.com (29.05.2019).

Stelarc. Ear on Arm. Retrieved from: http://stelarc.org/?catID=20242 (29.05.2019).

\begin{abstract}
The paper presents the notion of postphenomenology and implies that postphenomenological body is both sensual and spiritual. It is ambivalent, perhaps even paradoxical. Postphenomenological approach to the problem of corporeality seems somewhat different, which is most pointedly evidenced by Henri Maldiney's reflections, or the work of Jean-François Lyotard, on the borderline of phenomenology. They perceive subjectivity as sensual and affective, haunted by the sensual fact and, paradoxically, formed in an act tantamount to its destruction and abolition. On the other hand, the body also turns out to be invisible and filled with symbolism, it refers to the metaphysical dimension, turning us towards incarnation in the Christian sense, which is superbly illustrated in the writings of Michel Henry and Jean-Luc Marion, but also Jean-Louis Chrétien. As such, postphenomenology seems a perfectly suitable method for describing the work of artists who, for instance, as Marion LavalJeantet, injected herself horse blood plasma or make bread containing fragments of their own DNA with a view to ritually consuming it, as Karolina Żyniewicz did.
\end{abstract}

